\title{
On the Use of Images in Israel and the Ancient Near East
}

\author{
A Response to Karel van der Toorn
}

\author{
JACK M. SASSON \\ Vanderbilt University
}

I begin with three obvious points:

I. It is a fact that no new texts are being added to Hebrew Scriptures, whether by excavating in Jerusalem or in library vaults. In effect, to press our favorite individual points we still mine the same scriptural passages.

2. It is also a fact that archaeologists are recovering very few types of statues and images that were unknown to recent generations of scholarship. The material from Kuntillet al-'Ajrûd is one exception, the true usefulness of which, however, is compromised by sensationalizing articles in such publications as the Biblical Archaeology Review and Bible et Archéologie.

3. It is further a fact that the range of comparative material we can bring to bear on the issue of cult figurines, both textual and archaeological, has not changed much since the first decades of decipherment, although the testimony for each type of material has increased and our tools to analyze them have added in sophistication. If one draws on classical texts as witness, it will be seen that the evidence has been staring at us for a long time now.

Van der Toorn's approach to the problem of Israelite cultic practices is to avoid privileging one sort of documentation (for example, archaeological) over another (for example, textual). By leaning on comparative data drawn mostly from western Asia, van der Toorn has concluded that, prior to the Deuteronomistic reforms, worship in Israel was likely iconic. The arguments he gives are fivefold. I comment as I review them.

(I) While acknowledging the existence of a debate in ancient Israel about the cultic use of images, van der Toorn locates the sharpest interdictions against the cultic use of images in Deut 5:8 and 4:16 and therefore 
presumes that before that time the issue was more fluid. Even if we grant his premise, must we nevertheless assume that the most effective application of a legal formulation necessarily coincided with its fullest or most decisive codification? Especially in the case of Israel, when we have no extrabiblical materials, I think it behooves us to be wary. What if we operated on the assumption that a given social condition in Mesopotamia must be coeval with its formulation by Hammurabi and no earlier? Obviously, such an assumption would not be a fruitful premise.

(2) Van der Toorn's second argument: Israel's neighbors had temples, where they had images; Israel had temples, so Israel should have had at least one cultic image. If it did not have such an image, it would have carried out its worship in the open-air sanctuaries. Thin, very thin.

In fact, in antiquity, willingly or otherwise, the gods traveled constantly, spending quite a bit of time outside of their temples and receiving adoration at designated shrines. At Emar, images of the gods were displayed in the open air, where they doubtless received worshipers. Relevant for our discussion is the disagreement among specialists whether before the second millennium Mesopotamians ever worshiped the gods themselves, anthropomorphically or otherwise, rather than just their symbols. If so, at least for Mesopotamia, the worship of the gods incarnated into images may well have to be set within a move in historical times toward greater intimacy between gods and human beings. Applied to Israel, this observation suggests the opposite of van der Toorn's scheme: Deuteronomy might be a last-ditch attempt at retaining aniconic worship.

(3) For his third point, van der Toorn writes about the bronze serpent, the bulls of Bethel, and the idols of Micah. Although the implication of Flaubert's famous quip "Le Bon Dieu est dans le bétail [Flaubert has 'détail']" must never be dismissed in connection with religious symbolism, I nevertheless think that we need to accentuate the difference between cult images, figurines in which the divine presence was invested, and figurines that were merely decorative or served as acolytes. I will come back to this point below.

(4) For his fourth argument, van der Toorn focuses on the testimony of Kuntillet al-'Ajrûd regarding Yahweh and his Asherah, a testimony that in its wake has led to a profitable search for the mention of Asherot in published Northwest Semitic texts. The point he makes is about the existence of a consort for the Hebrew God. The material he brings into comparison is good and should not be dismissed out of hand. Yet I do want it remembered that, while at Elephantine and in gnostic texts (not to speak of medieval Jewish cabalistic texts), all sorts of brides were promoted for Yahweh, we must not assume that all these shiduchs originated in Israel's highest priestly circles or that such arrangements were deemed equally vital to the conduct of its cult. 
(5) Van der Toorn's fifth point deals with the psychology of worshipspecifically, with the difficulty of disassociating the anthropomorphic from our experience of the divine. This is true, and Voltaire said it most pungently when he claimed that if donkeys had gods they would conceive them in their own image. Still, I do not think we will advance too far if we take this analytic path. For in ancient Israel, as well as among its neighbors generally, the condition was at least partially caused by language, since Hebrews could not avoid creating anatomical metaphors when they reached for the abstract. I for one would not have students search for red-nosed figurines just because in Hebrew this is what is said to happen to Yahweh's nose when he lost patience. Further, we all know what it cost Ezekiel when in his early chapters he tried to avoid anthropomorphisms while speaking about God: he fractured grammar, blurred gender, ignored number, and played havoc with syntax; in short, he gave us bizarre, realistically impossible, visions. For his troubles, his text is now mercilessly emended, especially by biblical scholars with little appreciation of what he was trying to do.

In the second portion of his essay, van der Toorn does us a great service by suggesting diverse contexts for the use of figurines. Myself, I would not worry about the distribution of figurines within or beyond the "official cult," because to me the distinction is artificial. Van der Toorn categorizes as "votive" the largest number of figurines found in Israel. This is attractive, although it bears repeating that, when inscribed, Mesopotamian votive figurines tended to represent the worshipers as readily as the deities to whom they were offered. I find very quaint his suggestion that figurines dug up in Israel were clones that were destined for something like a tourist trade. I would ask van der Toorn to speculate about how much divinity remained stuck to such replicas. If not much, what was the point of shelling out shekels for their purchase? But if they retained enough of the divine aura, then I do not think there could have been much haste in wishing to purchase them, for the average worshipers of antiquity, especially those not belonging to priestly or royal circles, would not have relished transporting deities or their symbols. (Think of what 2 Samuel 6 says happened to poor Uzza when he accidentally touched a holy object!) To the contrary, fear and trembling were the prevalent reactions about coming into contact with them, as for instance when the veracity of litigants was tested through the handling of divine paraphernalia-so much so, that in many texts we are told that people would rather accept penalties than anger the gods. Having a god in your midst was also very unsettling to say the least. Think also of what happened to the poor Philistines when they commandeered the ark of Yahweh!

Among his final remarks, van der Toorn leaves open the possibility that Yahweh figurines may well have existed, especially among the figurines that 
portray riders and horses. Let me address this issue by connecting temples and cult figurines. ${ }^{\mathrm{I}}$

When we hear about the building of temples in the ancient Near East, those taking credit for the endeavor are almost uniformly rulers and elite. This is not surprising, because most of our records on this topic, especially foundation inscriptions and the like, were sponsored by kings. Now and then, however, we learn that temples, doubtless more modest in size, were raised by private individuals. Among the more arresting of these documents is one from Emar where a Pilsu-Dagan built a temple for an avatar of Nergal. Then, at a convocation of the city's elders, Pilsu-Dagan had his own descendants declared perpetual priests. ${ }^{2}$ Such enterprises may not have been uncommon, especially beyond the walls of administrative capitals. Thus, Judges 17 , which tells how Micah supplied his temple with cult figurines and priestly personnel, may be testimony to it. Interestingly enough, central administrations may have encouraged the burgeoning of smallish temples, for they facilitated their control of outlying regions merely by inviting these local gods for extended stay in the palace temple. Thus, in the Saggaratum district of Mari, the gods of local villages-really hovels-were gathered into the central palace, to be released in time for local festivals. ${ }^{3}$

Mari documents tell us also about the fabrication of cultic figurines. These figurines must not be confused with protective spirits or votive representations of rulers. The manufacture of a potential host for the god was carried out under the most deliberate steps. We are told of oracular measures taken "regarding the god Lagamal, whether to give him a human face or to set a tiara of 8 horns topped by golden disk." 4 We also have queries on how to position the statues of acolytes around a statue of the god. Writes a Mari administrator, "On a raised platform, to the left, stands the statue of the god Amurru, bearing a scimitar (gamlum). Across from him stands my lord's statue

I. Some of the ideas expressed below are duplicated, with kind permission of the editors and publisher, in "The Image of Ancient Israel: Reacting to Conference Presentations," in Text, Artifact, and Image: Revealing Ancient Israelite Religion (ed. Gary Beckman and Ted J. Lewis; Philadelphia: University of Pennsylvania Press, forthcoming).

2. D. Arnaud, Textes syriens de l'Âge $d u$ Bronze récent (Aula Orientalis Supplementa I; 1991) I43-44, text no. 87. For an accessible treatment, see H. Avalos, "Legal and Social Institutions in Canaan and Ancient Israel," in Civilizations of the Ancient Near East (ed. J. M. Sasson et al.; New York: Scribners, 1995) 623.

3. See text no. 8 in Maurice Birot, Lettres de Yaqqim-Addu, gouverneur de Sagaratum (ARMT I4; Paris: Geuthner, 1976).

4. This fragment is extracted from M.7515 and cited by D. Charpin and J. M. Durand, "Notes de lecture: Texte aus dem Sînkāsid Palast," MARI 7 (1993) 372. 
in worship. Atop the statue (of Amurru?), there is a sun-disk and mooncrescent." 5

Above all, no figurine could serve as object of worship if it were not first consecrated. This process required time-consuming rituals, such as rituals to open or wash the mouth of the potential god. Among the steps taken during such a ceremony was the formal disavowal that human hands were ever responsible for the creating of divine statues. ${ }^{6}$ Once these rituals were executed, what might look like a statue to an undiscerning mind had in fact become a visible manifestation of the unknowable, a palpable transfiguration of a "cosmic implosion," in which all that ever could be was rendered accessible to the human senses. 7 This is why we should really not be completely taken in by the Hebrew prophets when they mock pagans for their worship of dead wood and inert stone. In fact, like flags, crucifixes, and torah scrolls, the consecrated idol acquired sacralization because people, realizing how pathetically limited were their natural senses, had no other recourse by which to bridge the chasm separating them from their gods. If I were asked to elaborate on this observation, I would draw attention to the fact that in India (but also now in the United States) images of the gods are constructed, made divine, and then worshiped. ${ }^{8}$

The above remarks bring me back to the likelihood of archaeologists' ever finding cultic figures for Yahweh. For me it is not enough to dig up figurines of bulls or of humanoids riding equids; I would insist, rather, that before

5. This fragment is quoted from A.975, as cited in ibid.

6. This point is well made by Thorkild Jacobsen, "The Graven Image," in Ancient Israelite Religion: Essays in Honor of Frank Moore Cross (ed. P. D. Miller Jr., P. D. Hanson, and S. D. McBride; Philadelphia: Fortress, 1987) 15-32. See now Angelika Berlejung, Die Theologie der Bilder: Herstellung und Einweihung von Kultbildern in Mesopotamien und die alttestamentliche Bilderpolemik (Göttingen: Vandenhoeck \& Ruprecht, I 998) and her essay, "Washing the Mouth," in The Image and the Book: Iconic Cults, Aniconism, and the Rise of Religion in Israel and the Ancient Near East (ed. K. van der Toorn; Leuven: Peeters, 1997) 45-72. Also, Christopher Walker and Michael Dick, The Induction of the Cult Image in Ancient Mesopotamia: The Mesopotamian Mìs Pî Ritual (State Archives of Assyria Literary Texts I; Helsinki: The Neo-Assyrian Text Project, 2001).

7. The phrase is taken from J. Preston, who applies it to the mūrti in Hindu worship: "Creation of the Sacred Image: Apotheosis and Destruction in Hinduism," in Gods of Flesh, Gods of Stone: The Embodiment of Divinity in India (ed. J. P. Waghorne et al.; Chambersburg, Penn.: Anima, 1985) 9-30.

8. J. P. Waghorne, "The Divine Image in Contemporary South India: The Renaissance of a Once Maligned Tradition," in Born in Heaven, Made on Earth: The Making of the Cult Image in the Ancient Near East (ed. M. B. Dick; Winona Lake, Ind.: Eisenbrauns, 1999) 2 I I-43. 
scholars would offer as a serious hypothesis the existence of Yahweh figurines in the Hebrew cult, they should first refer to Scriptural evidence, manifest or vestigial, for consecrative ceremonies such as those discussed above.

So I remain skeptical about the conclusions of my colleague; but not about the need to periodically debate the place of cultic figurines in Israelite worship. Van der Toorn has correctly sensed that this debate, which is already a few centuries old, has recently come back to the fore, and with a vengeance. He offers three reasons for this situation:

I. The realization that religion addresses the senses as well as the mind;

2. The sentiment that popular religion is different from official cult;

3. The awareness that we have neglected the place of women (as in figurines).

I do not wish to argue with any of these points, although I would not want it imagined that Israel's religious practice is less sensuous when it is aniconic. ${ }^{9}$ I also do not want to debate a definition for popular religion, because, to be blunt about it, I don't think that we can distribute the textual and archaeological data about worship incontestably among the ranks, positions, and classes of an ancient society. When I hear talk of "popular religion," I feel carried back to the debate launched by the Social Gospel movement in America. ${ }^{10}$

I do, however, want to introduce another potentially cogent reason for our renewed fascination with the topic, because elucidating when we keep on rehashing old themes may also be worth our while.

It seems to me that beyond its intrinsic merits the debate about the place of cultic figurines in Israel's worship is quickened by cultural stresses of the type first described in biblical texts. The most spectacular of these debates lasted over a century and was launched most immediately when Leo III, emperor of Byzantium in the first half of the 8th century, championed the cause of iconoclasm and ordered the removal of icons and statues throughout the empire. He was challenged by powerful leaders, such as Popes Gregory II and III. What is interesting is that at the Second Nicean Council of 754 were paraded the same biblical texts that van der Toorn and others cite for proving or disproving the purity of Israel's worship. Thus, when Leo cited Hezekiah's destruction of Nehushtan, the bronze serpent, Gregory told him, "Yes, Heze-

9. To have witnessed Hebrew priests, in full raiment, slaughtering, butchering, burning, then dispensing of animals would certainly have quickened each of our senses-hearing, seeing, smelling, tasting, and touching--not to speak of the bother of having scads of buzzing flies, had we come upon the scene in midsummer.

Io. If not also to German romanticism when the Volk was invested with better creative instincts, in literature as well as in moral values 
kiah was certainly kin to you, displaying the same audacity as you, and in like manner tyrannized over the priests, for that serpent was brought into the temple by the holy David himself, together with the holy ark." ${ }^{1}$ Leo learned then what we all now know: you can argue antithetical positions, just by citing from Scripture.

Now specialists still ponder the causes that impelled Leo to arm the polemic with words when for centuries it was fought mostly with swords. I have come across many suggestions; but because I know so little about the context, I can unabashedly favor one of them. Under Leo, who was a usurper (most of them were in those days), "iconoclasm was the climax of caesoropapism, the traditional reestablishment of imperial cult." His reforms came from the heart, but they also made it such that none but the central administration could define and control what was an image and where to locate it. ${ }^{12}$ The parallels with what happened in Israel, in my opinion, are manifest.

I need not rehearse the iconomachy that took place at the Reformation; but I do want to stress that in the I 9 th century, when the issue was still driven by Protestants, the debate was ostensibly about the history of Israel and of its religion; but, not unlike what occurred in the creation of the documentary hypothesis, it was also about who, Catholic or Protestant, could claim the mantle as the truest inheritor of Israel's faith. During the zoth century, claims and arguments have not changed markedly. Within recent generations, the same evidence that van der Toorn has used to back up his thesis was called upon to explain the baleful influence Canaanite worship had on Israel's, and only a few voices (most prominently that of Erwin Goodenough) protested that the conjectures were dependent on biblical records that were accommodatingly sanitized. ${ }^{13}$

What has happened since those days to make the conclusions of van der Toorn more plausible today? Yes, we have refined our methodologies somewhat and have posed our questions differently; but I believe that the most radical change has taken place, not in our materials and methods, but in us and in our environment.

Since the early 1960s, Western Europe and America have been assimilating people from Asia, Africa, and the Caribbean who were once readily called "pagans." In many of our neighborhoods, we now have temples where the

I I. Quotation adapted from p. xxii of J. Mendham, The Seventh General Council, the Second of Niceae, in Which the Worship of Images Was Established (London: Painter, 1849 ).

12. See A. Cutler and P. A. Hollingsworth, "Iconoclasm," The Oxford Dictionary of Byzantium (ed. A. P. Kazhdan; Oxford: Oxford University Press, I 991 ) $2.975-77$.

13. See now Kalman Bland, The Artless Jew: Medieval and Modern Affirmations and Denials of the Visual (Princeton: Princeton University Press, 2000). 
worship of images is carried out: graven, theomorphic, anthropomorphic, gynecomorphic, and the like. I have noticed that a few more embellishments are now slipping into the decoration of Protestant churches than used to be found. I have also observed that Jewish ceremonial art, which once was relegated to secular buildings, is now being housed in museums attached to Jew. ish synagogues. We may well be adapting to a more tolerant, multicultural, and pluralistic phase of religious observance, where profundity of faith is not automatically linked to the suppression of artistic symbols. If so, then what better way to legitimize our gains than by showing, in meetings such as these, that even if Israel is proved to have worshiped through images of wood and stone, it was no less true to its instinct on the one and only God. 